NOTICE: this is the author's version of a work that was accepted for publication in Lithos. Changes resulting from the publishing process, such as peer review, editing, corrections, structural formatting, and other quality control mechanisms may not be reflected in this document. Changes may have been made to this work since it was submitted for publication. A definitive version was subsequently published in Lithos, Vol.190-191, (2014)]. DOI: 10.1016/j.lithos.2013.11.015 


\section{Partial melting of metabasic rocks in Val Strona di Omegna, Ivrea Zone,}

2 northern Italy

3

4

5

6

Barbara E. Kunz ${ }^{\mathrm{a}, 1, *}$, Tim E. Johnson ${ }^{\text {a }}$, Richard W. White ${ }^{\mathrm{a}}$, Charlotte Redler ${ }^{\mathrm{b}}$

${ }^{a}$ Earth System Science Research Centre, Institute for Geosciences, University of Mainz, Becherweg 21, D55099, Mainz, Germany

${ }^{b}$ Institute of Earth and Environmental Sciences, University of Freiburg, Albertstrasse 23b, D-79104 Freiburg, Germany

*Corresponding author. Tel.: +41 (0)31-631 4738; fax: +41 (0)31 6314843.

E-mail address: barbara.kunz@geo.unibe.ch (B.E. Kunz).

${ }^{1}$ Present address: Institute of Geological Sciences, University of Bern, Baltzerstrasse 1+3, CH-3012 Bern, Switzerland.

\section{ABSTRACT}

Field and petrographic observations combined with major and trace element bulk rock geochemistry show that metabasic rocks within Val Strona di Omegna in the central Ivrea Zone partially melted during granulite facies regional metamorphism. A transition from granoblastic amphibolite facies metabasic rocks at the lowest metamorphic grades to metatexitic and diatexitic migmatites in the granulite facies records the effects of in situ fluidabsent partial melting. Coarse-grained euhedral clinopyroxene porphyroblasts within leucosomes are consistent with anatexis via incongruent fluid-absent melting reactions consuming hornblende, plagioclase and quartz to form clinopyroxene and melt. Field observations are supported by bulk rock geochemistry, in which high-grade samples are generally depleted in mobile elements relative to unmigmatised mid amphibolite facies rocks 
that may approximate pre-melting protolith compositions. Many of the metabasic rocks at the highest-grade parts of Val Strona di Omegna probably belong to the Kinzigite Formation and are unlikely to be part of the younger Mafic Complex as previously proposed.

Keywords: In situ partial melting, metabasic rocks, granulite facies regional metamorphism, Ivrea Zone

\section{Introduction}

The main driving forces for differentiation of the Earth are partial melting and buoyancy-driven migration of melt. These processes are irreversible and have led to the pronounced physico-chemical structure of the continental crust (e.g., Brown and Rushmer, 2006; Sawyer et al., 2011). As direct observation of these processes is not possible, information regarding pressure-temperature $(P-T)$ conditions, melt compositions and the degree and mechanisms of the production, segregation and migration of melt are largely derived from the study of migmatites (e.g., Sawyer, 2008).

The Ivrea Zone in northern Italy (Fig. 1) exposes a section through the mid to lower continental crust and has been the focus of numerous studies, most of which have concentrated either on metapelitic rocks within the Kinzigite Formation (e.g., Barboza and Bergantz, 2000; Bertolani, 1968; Ewing et al., 2013; Handy et al., 1999; Luvizotto and Zack, 2009; Mehnert, 1975; Redler et al., 2012, 2013; Zingg, 1978) or on the layered mafic intrusions from the Mafic Complex (e.g., Peressini et al., 2007; Quick et al., 1992, 1994, 2009; Rivalenti et al., 1975, 1981; Sinigoi et al., 2011). The river section of Val Strona di

Omegna preserves a near-continuous metamorphic field gradient from mid-amphibolite to granulite facies conditions in which metapelitic compositions preserve a transition from 
unmelted (subsolidus) to partially melted (migmatitic) rocks (e.g., Redler et al., 2012, 2013; Schmid and Wood, 1976; Zingg, 1980). This study focusses on metabasic rocks that are interlayered with the metapelitic rocks in the Kinzigite Formation and which, though volumetrically abundant, have received relatively little attention (Reinsch, 1973a,b; Rushmer, 1991; Sills and Tarney, 1984). Emphasis is on detailed field and petrographic observations augmented with whole rock geochemical data that together provide evidence that, along with the metapelitic rocks, the metabasic rocks within Val Strona di Omegna partially melted during high temperature regional metamorphism.

\section{Geological setting} 65

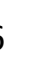
basement located in northern Italy. It is bordered to the northwest by the Insubric Line (also known as the Periadratic Line) that separates it from Alpine Units of the Canavese and Sesia Zones (Gansser, 1968), (Fig. 1). The Insubric Line is a 1-2 km wide zone of intense mylonitisation forming part of a major tectonic structure that can be traced from the French Alps in the west to Greece in the east, and which separates the Central/Western Alps from the Southern Alps (Gansser, 1968; Schmid et al., 1987). To the southeast, the Cossato-MergozzoBrissago Line (CMB Line) and the younger Pogallo Line separate the Ivrea Zone from the Strona-Ceneri Zone, which records greenschist to lower amphibolite facies assemblages and contains granitic plutons of Permian age and coeval volcanic rocks (Quick et al., 2009) that are locally covered by Mesozoic sediments. The Strona-Ceneri Zone represents a section through a shallower crustal level to that exposed in the Ivrea Zone (Boriani and Sacchi, 1973; Boriani et al., 1990), although it is unclear whether the Strona-Ceneri Zone and the Ivrea Zone represent a once contiguous crustal fragment or are discrete crustal terranes that were tectonically juxtaposed (Boriani and Sacchi, 1973). 
In the southwestern part of the Ivrea Zone (Fig. 1), mafic rocks of the Mafic Complex

and ultramafic rocks of the Balmuccia mantle peridotite crop out close to the Insubric Line (e.g., Quick et al., 1995, 2003; Rivalenti et al., 1975, 1981; Sinigoi et al., 1994, 2011). The Mafic Complex, which reaches a maximum thickness of around $8 \mathrm{~km}$ in Val Sesia, is a layered sequence of mafic/ultramafic rocks thought to have been formed by magmatic underplating in an extensional environment (Quick et al., 1992). The Mafic Complex has been subdivided into a lower unit, consisting mainly of amphibole gabbros and a 'paragneissbearing belt' in which the mafic rocks contain septa of paragneiss, and an upper unit, which is dominated by gabbros and diorites (Sinigoi et al., 1996).

The Kinzigite Formation crops out extensively within the central part of the Ivrea Zone and is best exposed in Val Strona di Omegna (Fig. 1). It is cross cut by the Mafic Complex in the southwest. The Kinzigite Formation comprises different rock types, the most common of which are metapelitic and metabasic rocks with subordinate metapsammite, calcsilicate, marble and metaperidotite. All rocks were regionally metamorphosed at amphibolite to granulite facies conditions (e.g., Barboza and Bergantz, 2000; Barboza et al., 1999; Henk et al., 1997; Peressini et al., 2007; Pin, 1990; Redler et al., 2012; Zingg, 1978) with regional assemblages overprinted by contact metamorphism in close proximity to gabbroic rocks of the Mafic Complex (e.g., Barboza and Bergantz, 2000; Barboza et al., 1999; Redler et al., 2012). The pre-metamorphic history of the Kinzigite Formation is unclear, as the high-grade metamorphism and deformation have erased almost all evidence for older events (e.g., Schmid, 1993; Vavra et al., 1999). Peressini et al. (2007) date the intrusion of the Mafic Complex to $288 \pm 4 \mathrm{Ma}$ and high-grade metamorphism in the Kinzigite Formation to $309 \pm 3$ Ma. More recent work by Ewing et al. (2013) suggests regional granulite facies metamorphism in Val Strona di Omegna occurred at $316 \pm 3$ Ma. $P-T$ estimates from the Kinzigite Formation are mostly based on metapelitic samples and range from $\sim 600^{\circ} \mathrm{C}$ and $3-4$ kbar for the lowest grade rocks to in excess of $900^{\circ} \mathrm{C}$ and $10-12 \mathrm{kbar}$ for the highest grade 
granulite facies rocks (e.g., Bea and Montero, 1999; Ewing et al., 2013; Hunziker and Zingg, 1980; Luvizotto and Zack, 2009; Redler et al., 2012; Schmid et al., 1987).

A detailed petrographic study in Val Strona di Omegna (Reinsch, 1973a) subdivided the metabasic rocks within the Kinzigite Formation (from relatively low to high grade) into: (i) amphibolites dominated by hornblende and plagioclase with minor quartz and biotite; (ii) garnetiferous metagabbros ('banded pyribolites') containing plagioclase, garnet, hornblende and pyroxene and; iii) rare 'pyriclasites' containing plagioclase, clino- and orthopyroxene, quartz and biotite. Based on their bulk rock major element composition, Reinsch (1973b) classified the amphibolites as having alkali-basaltic to dacitic protoliths and the garnetiferous metagabbro and 'pyriclasites' as representing metamorphosed alkali to hypersthene-bearing basalts. $P-T$ conditions were estimated at $700^{\circ} \mathrm{C}$ and $4-6 \mathrm{kbar}$ for the amphibolite facies metabasic rocks and $750-850^{\circ} \mathrm{C}$ and $6-8 \mathrm{kbar}$ for the granulite facies metabasic rocks (Reinsch, 1973b). Using trace element geochemistry, Sills and Tarney (1984) identified two separate groups of amphibolites within Val Strona di Omegna. Type 1 amphibolites have trace element patterns similar to N-MORB while type 2 amphibolites show patterns similar to EMORB.

\section{Field and petrographic observations}

$$
\text { ranging in width from } 10 \mathrm{~cm} \text { to around } 100 \mathrm{~m} \text { that are interlayered with the metapelitic rocks. }
$$
Based on changes in mineral assemblages, the valley can be subdivided into three different sections based on metamorphic (sub)facies: the mid amphibolite facies, the upper amphibolite facies and the granulite facies (Fig. 2). The major mineral assemblage of samples is given in Table 1. Mineral abbreviations follow Kretz (1983) and migmatite terminology follows Sawyer (2008). 


\subsection{Mid amphibolite facies}

134

Mid amphibolite facies rocks are exposed from the lowest grade outcrops close to the CMB Line at the village of Germagno to the village of Marmo, some six kilometres to the northwest (Fig. 2). The upper (higher grade) boundary of the mid amphibolite facies is defined by the first obvious occurrence of clinopyroxene in metabasic rocks, which occurs close to the K-feldspar in/muscovite out isograd in metapelitic rocks (Redler et al., 2012). Within this section, the metabasic rocks occur as weakly-foliated NE-SW oriented pods and lenses in which secondary veins of quartz or calcite are common (Fig. 3a). Some samples contain porphyroblasts of hornblende or, rarely, garnet, and some preserve a foliation defined by biotite and hornblende (Fig. 4a). No macroscopic or microscopic evidence for partial melting has been identified in metabasic rocks in the mid amphibolite facies.

The typical mineral assemblage of mid amphibolite facies metabasic rocks is (green) hornblende, plagioclase, quartz, biotite and ilmenite (Table 1), with garnet additionally present in one sample (IZ 027). K-feldspar, chlorite, pyrite, apatite, chalcopyrite, hematite, zircon and/or calcite occur as minor or accessory phases. Hornblende (typically $0.1-10 \mathrm{~mm}$ in length) is lepidoblastic and pleochroic from intense green to beige and may be partially to completely replaced by biotite (Fig. 4a). Plagioclase $(0.1-2 \mathrm{~mm})$ is anhedral and is commonly partially seriticised. Quartz $(<0.1-5 \mathrm{~mm})$ is granoblastic and exhibits undulose extinction. Biotite $(0.1-3.5 \mathrm{~mm})$ is pleochroic from dark brown to beige and has a lepidoblastic habit (Fig. 4a). Ilmenite and other opaque phases have a maximum length of $0.5 \mathrm{~mm}$, are commonly elongated subparallel to the foliation and occur both within the matrix and as inclusions in hornblende and garnet. Garnet within sample IZ $027(0.5-3.5 \mathrm{~mm})$ is skeletal and contains numerous inclusions of ilmenite and hornblende. 


\subsection{Upper amphibolite facies}

The upper amphibolite facies section is here defined as the section of the valley between the first noted occurrence of clinopyroxene (north of the village of Marmo) to the first appearance of orthopyroxene (near the village of Forno) in metabasic rocks (Fig. 2), and is elsewhere referred to as the 'Transition Zone' (Bea and Monero, 1999). At the lower-grade end there is no obvious macroscopic change in the appearance of the metabasic rocks relative to lower-grade rocks. Approximately one kilometre northwest of the village of Marmo (Fig. 2), the metabasic rocks contain segregations concentrating either leucocratic or melanocratic minerals that occur as layers aligned subparallel to the foliation. Towards higher grades, south of the village of Rosarolo (Fig. 2), the metabasic rocks become more granoblastic and the first clear evidence for in situ partial melting is visible. Small quartzofeldspathic leucocratic patches (leucosome) with a diameter of 2-5 cm occur with and/or enclose pale green clinopyroxene porphyroblasts (5-35 $\mathrm{mm}$ in diameter) (Fig. 3b). Melanocratic layers (melanosome) are dominated by green-brown hornblende with minor plagioclase and quartz. At the high-grade end of the upper amphibolite facies section, south of Forno (Fig. 2), discrete clinopyroxene-bearing leucosome veins cross-cut the foliation (Fig. 3c).

The main mineral assemblage of the upper amphibolite facies metabasic rocks is clinopyroxene, green/brown hornblende, plagioclase, quartz and ilmenite (Table 1). Minor and accessory phases include sphene, garnet, rutile, biotite, zircon, chlorite, pyrite, calcite, chalcopyrite, hematite and/or apatite. In thin section, subhedral, near-colourless clinopyroxene ranges in size from $0.5 \mathrm{~mm}$ in the matrix to porphyroblasts up to $35 \mathrm{~mm}$ across (Fig. $4 \mathrm{~b}$ ). In some samples clinopyroxene is extensively replaced by hornblende. Strongly-pleochroic anhedral to euhedral hornblende $(0.5-5.5 \mathrm{~mm})$ occurs as both green and brown variants, in which the proportion of brown hornblende increases upgrade. Close to the granulite facies transition only brown hornblende is present. Plagioclase $(0.5-4.5 \mathrm{~mm})$ and quartz (average 0.5 
$\mathrm{mm}$ but up to $10 \mathrm{~mm}$ ) are anhedral. Ilmenite and other opaque phases occur as sub-rounded grains up to $1 \mathrm{~mm}$ across.

\subsection{Granulite facies}

Granulite facies assemblages are preserved in rocks from the village of Forno to the Insubric Line northwest of Campello Monti (Fig. 2). Granulite facies metabasic rocks have a coarser grain size compared with amphibolite facies rocks and contain conspicuous porphyroblasts of clinopyroxene up to $5 \mathrm{~cm}$ and garnet up to $10 \mathrm{~cm}$ in diameter (Fig. $3 \mathrm{~d}-\mathrm{j}$ ). Field relationships between the different rock types are complex due to an inferred increase in the degree of partial melting of both metapelitic and metabasic rocks. Close to lithological contacts metabasic rocks commonly contain veins and patches of leucosome derived from the metapelitic rocks, and the origin of individual leucosomes may be ambiguous (Redler et al., 2013)

Most leucosomes occur as veins (millimetres to decimetres thick) that form either interconnected networks or more irregular bodies concentrated within interboudin partitions or folds hinges (Fig. 3d-i). Leucosomes generated within, or derived from, the metabasic rocks are mostly dominated by plagioclase and quartz and contain peritectic clinopyroxene that is partly retrogressed to hornblende (Fig. $3 \mathrm{~h}, \mathrm{j}$ ). The melanosome is generally dominated by clinopyroxene and garnet with varying amounts of orthopyroxene, hornblende and biotite. In some places hornblende-rich selvedges are spatially associated with leucosome and form irregular patches a few centimetres across (Fig. 3h). Some of the rocks preserve scarce field evidence for partial melting (i.e. they lack obvious leucosome), although in thin section these samples have residual mineral assemblages dominated by pyroxene and garnet with little to no amphibole and plagioclase. However, most granulite facies metabasic rocks are 
metatexites, comprising stromatic or patch migmatites. Metabasic diatexites are rare and occur locally only at the highest grades.

Granulite facies metabasic rocks contain clinopyroxene, orthopyroxene, brown hornblende, plagioclase, biotite, ilmenite, garnet and quartz (Table 1), with minor rutile, sphene, zircon, K-feldspar, hematite, chlorite, pyrite, chalcopyrite, apatite and/or calcite. Matrix clinopyroxene occurs most commonly as subhedral grains with an average size of 0.5 mm (Fig. 4c-f). Clinopyroxene porphyroblasts are euhedral, up to $35 \mathrm{~mm}$ across, and may contain exsolution lamellae of orthopyroxene. In the highest-grade sample (IZ 100), clinopyroxene is pale green in thin section. Clinopyroxene may contain inclusions of garnet, ilmenite and biotite and is commonly partially to completely replaced by hornblende, which is itself commonly replaced by biotite (Fig. $4 \mathrm{~h})$. Orthopyroxene $(<0.5-2 \mathrm{~mm}$ in the matrix) is morphologically similar to clinopyroxene, although in most samples orthopyroxene is much less abundant (Fig. 4 c-f). Porphyroblasts of orthopyroxene with a grain size larger than $5 \mathrm{~mm}$ are uncommon. Hornblende forms granoblastic subhedral to euhedral grains that are pleochroic from dark brown to beige and range in size from $<0.25 \mathrm{~mm}$ in the matrix to porphyroblasts up to $5 \mathrm{~mm}$ across (Fig. $4 \mathrm{c}-\mathrm{h}$ ).

Where present, garnet mostly occurs as subhedral, skeletal porphyroblasts up to $5 \mathrm{~mm}$ across containing numerous inclusions of hornblende, clinopyroxene, orthopyroxene, plagioclase, biotite, quartz and ilmenite (Fig. 4 c,d,g). In the highest-grade samples, garnet occurs as euhedral pale pink crystals with a grain size of 5-100 mm. These large garnet porphyroblasts are commonly surrounded by a layered corona with an inner plagioclase-rich layer and outer hornblende-rich layer (Fig. $4 \mathrm{~g})$. Lepidoblastic biotite $(0.1-1 \mathrm{~mm})$ is more common in the granulite facies metabasic rocks relative to upper amphibolite facies samples. Plagioclase within the melanosome is anhedral to subhedral with an average grain size of 1 $\mathrm{mm}$; quartz is mostly subhedral, shows undulose extinction and has a maximum grain size of $0.1 \mathrm{~mm}$. In leucosome veins, plagioclase and quartz can be several centimetres across. 
Ilmenite is coarse grained (up to $1 \mathrm{~mm}$ ) and commonly occurs as inclusions in garnet, pyroxene or hornblende.

\section{Whole rock geochemistry}

\subsection{Analytical Methods}

Bulk rock major and trace element compositions of 31 samples were determined by Xray fluorescence spectroscopy (XRF) and Laser Ablation Inductively Coupled Plasma Mass Spectrometry (LA-ICP-MS) at the Institute for Geoscience, University of Mainz. For XRF analysis, a representative unaltered part of the sample was crushed and milled to a grain size of less than $63 \mu \mathrm{m} .0 .4 \mathrm{~g}$ of the sample powder was mixed with $5.2 \mathrm{~g}$ of flux $\left(\mathrm{Li}_{2} \mathrm{~B}_{4} \mathrm{O}_{7}\right)$ (corresponding to a 14-times dilution) and fused to glass beads in a Pt-cylinder. Samples were analysed by X-ray fluorescence using a Philips Magix Pro for $\mathrm{SiO}_{2}, \mathrm{Al}_{2} \mathrm{O}_{3}, \mathrm{Fe}$ (total), $\mathrm{MnO}$, $\mathrm{MgO}, \mathrm{CaO}, \mathrm{Na}_{2} \mathrm{O}, \mathrm{K}_{2} \mathrm{O}, \mathrm{TiO}_{2}, \mathrm{P}_{2} \mathrm{O}_{5}, \mathrm{SO} 3, \mathrm{Cr}_{2} \mathrm{O}_{3}$ and $\mathrm{NiO}$. Accuracy for major element concentrations was $<1 \%$ relative except for $\mathrm{MnO}(2 \%)$ and $\mathrm{Na}_{2} \mathrm{O}(1.5 \%)$. The loss on ignition (LOI) was taken as a direct proxy for the $\mathrm{H}_{2} \mathrm{O}$ content. Selected trace element ( $\mathrm{Sc}, \mathrm{Cr}$, $\mathrm{Ni}, \mathrm{Rb}, \mathrm{Pb}$ ) were also measured by $\mathrm{XRF}$, in which $6 \mathrm{~g}$ of the rock powder were mixed with two component epoxy and pressed to a tablet. The trace elements $\mathrm{Cs}, \mathrm{Ba}, \mathrm{Th}, \mathrm{U}, \mathrm{Nb}, \mathrm{Ta}, \mathrm{La}$, Ce, Pr, Nd, Sr, Sm, Hf, Zr, Ti, Eu, Gd, Dy, Ho, Y, Er, Yb and Lu were determined by LAICP-MS. Sample powders were fused to glass beads on an iridium strip heater under an Aratmosphere (Nehring et al., 2008) then analysed with an Agilent 7500 quadrupole ICP-MS coupled with a New Wave Research UP-193nm laser ablation system. The background was measured for $30 \mathrm{~s}$ prior to sample analysis. Standardisation after every 10 th measured spot used standard NIST SRM 612. Ca values measured by XRF were sued as an internal standard. At the beginning and the end of the analytical run, standard NIST SRM 610 was measured to 
ensure consistency. Data reduction used the software 'Glitter'. Table 2 gives the major and trace element composition for eight representative samples from Val Strona di Omegna.

\subsection{Major elements}

Figure 5 shows selected major element oxide variation diagrams for the metabasic rocks. Although there is considerable variation in the composition of samples, some general trends are recognisable. $\mathrm{SiO}_{2}$ contents range between 41 and $56 \mathrm{wt} \%$, in which the mid amphibolite facies samples generally have the highest $\mathrm{SiO}_{2}$ contents, with rocks from higher grades relatively depleted in $\mathrm{SiO}_{2}$. A similar trend is observed for $\mathrm{K}_{2} \mathrm{O}$ contents $(0.3-1.5$ wt\%), which are highest in the mid amphibolite facies rocks and lowest in the granulite facies rocks. Although there is significant overlap, the concentrations of $\mathrm{TiO}_{2}(0.6-3.2 \mathrm{wt} \%), \mathrm{Al}_{2} \mathrm{O}_{3}$ (13-24 wt \%), $\mathrm{CaO}(6-17 \mathrm{wt} \%)$, total iron as $\mathrm{FeO}(6-19 \mathrm{wt} \%)$ and $\mathrm{MgO}(2.0-8.5 \mathrm{wt} \%)$ generally increase from low- to high-grade samples. Concentrations of $\mathrm{MnO}(0.07-0.4 \mathrm{wt} \%)$ and $\mathrm{Na}_{2} \mathrm{O}(0.5-3.7 \mathrm{wt} \%)$ are highly variable and exhibit no clear correlation with metamorphic grade.

\subsection{Trace elements}

There is considerable variability in the trace element composition of samples. Figure 6 shows concentrations of selected trace elements within the metabasic rocks normalised to primitive mantle (PM) values (McDonough and Sun, 1995) with elements ordered by increasing compatibility in oceanic basalts (Hofmann, 1988). The composition of average NMORB, E-MORB (Hofmann, 1988; Sun and McDonough, 1989) and of the middle and lower continental crust (Rudnick and Gao, 2003) are shown for reference. 
Samples from the mid amphibolite facies (Fig. 6a) have trace element concentrations that generally fall within the compositional range of average middle to lower continental crust, although two samples are relatively enriched in $\mathrm{Nb}$ and $\mathrm{Ta}$. The $\mathrm{Hf}$ and $\mathrm{Zr}$ concentrations show two distinct groups, one with concentrations similar to average middle continental crust and another with trace element compositions depleted with respect to NMORB. Samples from the upper amphibolite facies samples (Fig. 6b) generally show less variability than mid amphibolite and granulite facies samples. With the exception of $\mathrm{Ba}, \mathrm{Th}$ and Sr, LILE are enriched in upper amphibolite rocks compared to N-MORB whereas other trace elements have concentrations between average $\mathrm{N}$ - and E-MORB. The granulite facies samples show the most variable trace element compositions (Fig. 6c). With the exception of four samples that show a strong negative Th anomaly, all are enriched in LILE compared to N-MORB. Similar to mid amphibolite facies samples, granulite facies samples can be separated into two groups based on their $\mathrm{Nb}$, Ta and $\mathrm{Hf}, \mathrm{Zr}$ contents.

Figure 7 shows rare earth element (REE) concentrations in metabasic rocks from Val Strona di Omegna normalised to CI chondrite values (Sun and McDonough, 1989). (La/Lu) ${ }_{\mathrm{N}}$ ratios are variable in both mid amphibolite facies (1.1-10.5) and granulite facies (1.0-8.8) samples. However, upper amphibolite facies samples generally have more uniform REE patterns with $(\mathrm{La} / \mathrm{Lu})_{\mathrm{N}}<1,(\mathrm{La} / \mathrm{Sm})_{\mathrm{N}}<1$ and $(\mathrm{Gd} / \mathrm{Lu})_{\mathrm{N}} \sim 1$. With the exception of one sample, upper amphibolite facies samples show REE patterns similar to average N-MORB. The LREE concentrations in the mid amphibolite facies show two distinct trends; three samples show concentrations similar to average E-MORB and lower continental crust with $(\mathrm{La} / \mathrm{Sm})_{\mathrm{N}}$ ratios of $0.7-1.4$ whereas three others have values comparable to average middle continental crust, with $(\mathrm{La} / \mathrm{Sm})_{\mathrm{N}}$ ratios of 2.6-3.6. The HREE patterns in the mid amphibolite facies are flat with $(\mathrm{Gd} / \mathrm{Lu})_{\mathrm{N}}$ ratios between 1.1-2.6, similar to granulite facies samples $\left[(\mathrm{Gd} / \mathrm{Lu})_{\mathrm{N}}=1-3\right]$. Most granulite facies samples show relative flat LREE patterns with $(\mathrm{La} / \mathrm{Sm})_{\mathrm{N}}$ ratios of $0.5-$ 2.4 but range from compositions similar to N-MORB to samples with concentrations higher 
than those in average middle continental crust. Pronounced europium anomalies are not evident in the metabasic rocks from Val Strona di Omegna $\left(\mathrm{Eu} / \mathrm{Eu}^{*}=0.5-1.5\right)$. Two mid amphibolite facies samples and two-thirds of granulite facies samples show a small negative europium anomaly whereas no europium anomaly is evident in upper amphibolite facies samples. A comparison of the bulk rock trace element composition (Fig. 6d; 7d) of metabasic rocks sampled close to Campello Monti (this study; Fig. 2) and mafic rocks from the Mafic Complex (taken from Sinigoi et al., 2011) show large variability in which a clear compositional distinction between rocks within the Kinzigite Formation and the Mafic complex cannot be made.

\section{Discussion}

Studies of migmatites provide physico-chemical constraints on the processes of melt production, segregation and migration. Peak temperatures in excess of $700^{\circ} \mathrm{C}$ are commonly recorded by rocks in the highest-grade parts of regional metamorphic belts, in which numerous studies have documented evidence for fluid-absent partial melting of metapelitic rocks (e.g., Sawyer, 2008). However, under 'normal' (Barrovian) regional metamorphic geothermal gradients, and in the absence of an external supply of $\mathrm{H}_{2} \mathrm{O}$-rich fluids, much higher temperatures $\left(>\right.$ or $>>800^{\circ} \mathrm{C}$; Rushmer, 1991; Wyllie and Wolf, 1993) are required to produce significant quantities of melt from metabasic rocks. Petrological studies pertaining to the partial melting of these common mafic crustal protoliths are scarce (e.g., Hartel and Pattison, 1996; Johnson et al., 2012; Sawyer, 1991).

The results presented in this study show a broadly consistent mineralogical, textural and geochemical evolution from mid amphibolite to granulite facies conditions that support the interpretation that metabasic rocks within Val Strona di Omegna partially melted during high temperature regional metamorphism. Temperature estimates using the $\mathrm{Zr}$-in-rutile 
thermometer (Ewing et al., 2013; Luvizotto and Zack, 2009) and phase equilibria modelling of metapelitic rocks (Redler et al., 2012) indicate maximum metamorphic peak temperature conditions in excess of $900^{\circ} \mathrm{C}$ in Val Strona di Omegna. Such temperatures are sufficiently high that fluid-absent melting of metabasic lithologies via the incongruent breakdown of hornblende is inevitable at the highest metamorphic grades, providing the protoliths were sufficiently hydrated (Rushmer, 1991; Wyllie and Wolf, 1993).

Field observations provide unequivocal evidence that most of the high grade metabasic rocks within the Kinzigite Formation underwent in situ partial melting (Fig. 3). Mineral assemblages in the mid amphibolite facies are dominated by green-hornblende and plagioclase and the rocks preserve no clear evidence for partial melting. In the upper amphibolite facies the metabasic rocks additionally contain clinopyroxene and patches of quartzofeldspathic leucosome segregations containing centimetric clinopyroxene porphyroblasts that are significantly larger than clinopyroxene within the melanosome and which are interpreted as the solid (peritectic) product of the fluid-absent breakdown of hornblende, plagioclase and quartz to form clinopyroxene and melt (Fig. 3j-1; 4b; Johnson et al., 2012). These porphyroblast-leucosome relationships are consistent with the in-situ spatially-focussed formation of melt around the porphyroblasts (e.g., White et al., 2004; White, 2008). Close to the granulite facies boundary the metabasic rocks contain fine-grained stromatic leucosomes as well as coarse-grained, peritectic clinopyroxene-bearing leucosomes that cross cut the foliation (Fig. 3c). Granulite facies metabasic rocks contain near anhydrous assemblages dominated by clinopyroxene, garnet and plagioclase, with or without orthopyroxene, and exhibit features suggesting highly variable degrees of partial melting that are likely related to either the original $\mathrm{H}_{2} \mathrm{O}$ content of the protoliths (i.e. the amount of amphibole \pm biotite stable on crossing the solidus) and/or the textural development during melting and the efficacy of melt loss. Leucosome contents in granulite facies metabasic rocks are 10-20 vol.\% that, if produced in situ or in source, provide a minimum estimate on melt 
productivity. The limited degree of retrograde replacement of anhydrous minerals in rocks preserving evidence for partial melting requires loss of melt (White and Powell, 2002).

Although the major and trace element data show a large degree of scatter and overlap, the data are consistent with an interpretation of partial melting and melt loss. Figure 8 shows average major and trace element data of the upper amphibolite and granulite facies samples normalised to the average mid amphibolite facies samples. Assuming the average composition of mid amphibolite facies samples is a reasonable approximation for that of the unmelted protoliths, Fig. 8 shows an overall relative depletion in Na, K, LILE and possibly Si, Al and LREE in upper amphibolite and granulite facies rocks, mobile elements which are incompatible and will partition preferentially into the melt. In contrast, the more compatible elements Mg, Ca, Fe, Ti, HFSE and HREE are relatively enriched in the high-grade samples relative to their inferred protolith, consistent with these compositions representing residua following partial melting and melt loss.

However, upper amphibolite facies samples are in general more depleted in fluid mobile elements and more enriched in residual elements relative to the granulite facies samples (Fig. 8), which is inconsistent with a simple interpretation of partial melting and melt loss from compositions similar to an average lower amphibolite facies protolith. In addition, most granulite facies samples contain minor biotite whereas upper amphibolite facies samples do not. These differences might suggest different protolith compositions for upper amphibolite facies rocks relative to mid amphibolite and granulite facies rocks (e.g., Sills \& Tarney, 1984). Another plausible explanation could be the variable abundance of metapelitic rocks within Val Strona di Omegna. The detailed geological map of Bertolani (1968) shows that the proportion of metapelitic to metabasic rocks is high in the mid amphibolite and granulite facies sections relative to those in the upper amphibolite facies, where metabasic rocks dominate. At the highest metamorphic grades, where residual (i.e. melt-depleted) metapelitic rocks are volumetrically dominant (Schmid and Wood, 1976), nearby metabasic 
rocks are more likely to have interacted with metapelite-derived melt, leading to a relative enrichment in mobile elements and the growth of biotite. In upper amphibolite facies rocks, where metapelitic rocks are far less abundant, contamination with metapelite-derived components was more restricted, perhaps explaining why the rocks did not develop biotite. Metabasic rocks throughout the Ivrea Zone have a range of compositions that likely reflect complex magmatic process (e.g., heterogeneity of the source and fractionation) as well as variable degrees of interaction with and contamination by crustal material during prograde metamorphism (in case of pre- to syn metamorphic metabasic rocks) or emplacement (in the case of the mafic rocks within the Mafic Complex, Correia et al., 2012, Sinigoi et al., 2011). More detailed investigations (including isotopic analysis) are required to better constrain their petrogenesis. However, many metabasic rocks within Val Strona di Omegna have mineral assemblages consistent with metamorphic conditions constrained from the metapelitic rocks (e.g., Redler et al., 2012). In addition, prograde metamorphic features in these metabasic rocks are consistent with their protoliths having been emplaced and hydrated prior to, or at least in the early stages of, prograde metamorphism. The evidence for in situ melting and the occurrence of hornblende inclusions in porphyroblasts is consistent with these rocks having been sufficiently hydrous that they contained a substantial quantity amphibole during prograde metamorphism. Thus, many of the metabasic rocks in Val Strona di Omegna section experienced an identical prograde, peak and retrograde metamorphic history as the metasedimentary rocks that host them.

Previous studies have attributed all metabasic rocks around Campello Monti to the Mafic Complex (e.g., Capedri et al., 1977) whereas other ascribe all metabasic rocks in Val Strona di Omegna to the Kinzigite Formation (e.g., Bertolani, 1968). This study suggests that some of the metabasic rocks around Campello Monti show no distinct difference in metamorphic evolution, mineral assemblages, migmatite textures or whole rock composition 
when compared with other granulite facies rocks within the Kinzigite Formation, and these rocks should probably not be regarded as part of the Mafic Complex.

\section{Conclusions}

- Metabasic rocks within the Kinzigite Formation in Val Strona di Omegna show a continuous evolution from mid amphibolite facies to granulite facies conditions, the result of high-grade regional metamorphism;

- At the highest grades the metabasic rocks are migmatites, in which a close spatial relationship between leucosome and coarse-grained euhedral clinopyroxene provides evidence for in situ partial melting by reactions consuming hornblende, plagioclase and quartz;

- The bulk rock geochemistry of metabasic rocks within the Kinzigite Formation support an interpretation of partial melting and melt loss with variable interaction with melt derived from surrounding metapelitic rocks;

- Many of the metabasic rocks within the Kinzigite Formation were emplaced and hydrated prior to or during prograde metamorphism permitting in situ partial melting. They followed a similar metamorphic history (prograde, peak and retrograde) to the metasedimentary rocks in Val Strona di Omegna;

- Many of the metabasic rocks at the highest metamorphic grades within Val Strona di Omegna should be regarded as part of the Kinzigite Formation, not the Mafic Complex as previously proposed (e.g., Capedri et al., 1977).

\section{Acknowledgements}


geochemical analyses. We are grateful to S. Sinigoi and an anonymous reviewer for their helpful and perceptive reviews and to M. Scambelluri for his editorial handling.

\section{References}

Barboza, S.A., Bergantz, G.W., 2000. Metamorphism and anatexis in the Mafic Complex contact aureole, Ivrea Zone, Northern Italy. Journal of Petrology 41, 1307-1327.

Barboza, S.A., Bergantz, G.W., Brown, M., 1999. Regional granulite facies metamorphism in the Ivrea zone: Is the Mafic Complex the smoking gun or a red herring?. Geology 27, $447-$ 450.

Bea, F., Montero, P., 1999. Behavior of accessory phases and redistribution of Zr, REE, Y, Th, and $U$ during metamorphism and partial melting of metapelites in the lower crust: an example from the Kinzigite Formation of Ivrea-Verbano, NW Italy. Geochimica et Cosmochimica Acta 63, 1133-1153.

Bertolani, M., 1968. La petrografia della Valle Strona (Alpi Occidentali Italiane). Schweizerische Mineralogische und Petrographische Mitteilungen 48, 695-733.

Bigi, G., Castellarin, A., Coli, M., Dal Piaz, G.V., Sartori, R., Scandone, P., 1990. Structural model of Italy sheet 1, 1:500000. Consiglio Nazionale delle Ricerche, Progetto Finalizzato Geodinamica, SELCA Firenze.

Boriani, A., Giobbi Origoni, E., Borghi, A., Caironi, V., 1990. The evolution of the "Serie dei Laghi" (Strona-Ceneri and Scisti dei Laghi): the upper component of the Ivrea-Verbano crustal section; Southern Alps, North Italy and Ticino, Switzerland. Tectonophysics 182,

Boriani, A., Sacchi, R., 1973. Geology of the junction between the Ivrea-Verbano and Strona- 
Brown, M., Rushmer, T., 2006. Evolution and differentiation of the continental crust. Cambridge University Press.

Capedri, S., Coradini, A., Fanucci, O., Garuti, G., Rivalenti, G., Rossi, A., 1977. The origin of the Ivrea-Verbano Basic Formation (Italian Western Alps). Statistical approach to the peridotite problem. Rendiconti della Società Italiana di Mineralogia e Petrologia 33, 583592.

Correia, C.T., Sinigoi, S., Girardi, V.A.V., Mazzucchelli, M., Tassinari, C.C.G., Giovanardi, T., 2012. The growth of large mafic intrusions: Comparing Niquelândia and Ivrea igneous complexes. Lithos 155, 167-182.

Ewing, T.A., Hermann, J., Rubatto, D., 2013. The robustness of the Zr-in-rutile and Ti-inzircon thermometers during high-temperature metamorphism (Ivrea-Verbano Zone, northern Italy). Contributions to Mineralogy and Petrology 4, 757-779.

Gansser, A., 1968. The Insubric line, a major geotectonic problem. Schweizerische Mineralogische und Petrographische Mitteilungen 48, 123-143.

Handy, M.R., Franz, L., Heller, F., Janott, B., Zurbriggen, R., 1999. Multistage accretion and exhumation of the continental crust (Ivrea crustal section, Italy and Switzerland). Tectonics 18, 1154-1177.

Hartel, T.H.D., Pattison, D.R.M., 1996. Genesis of the Kapuskasing (Ontario) migmatitic mafic granulites by dehydration melting of amphibolite: the importance of quartz to reaction progress. Journal of Metamorphic Geology 14, 591-611.

Henk, A., Franz, L., Teufel, S., Oncken, O., 1997. Magmatic Underplating, Extension, and Crustal Reequilibration: Insights from a Cross-Section through the Ivrea Zone and StronaCeneri Zone, Northern Italy. The Journal of Geology 105, 367-377.

Hofmann, A.W., 1988. Chemical differentiation of the Earth: the relationship between mantle, continental crust, and oceanic crust. Earth and Planetary Science Letters 90, 297-314. 
Hunziker, J.C., Zingg, A., 1980. Lower Palaeozoic Amphibolite to Granulite Facies Metamorphism in the Ivrea Zone (Southern Alps, Northern Italy). Schweizerische Mineralogische und Petrographische Mitteilungen 60, 181-213.

Johnson, T.E., Fischer, S., White, R.W., Brown, M., Rollinson, H.R., 2012. Archaean Intracrustal Differentiation from Partial Melting of Metagabbro - Field and Geochemical Evidence from the Central Region of the Lewisian Complex, NW Scotland. Journal of Petrology 53, 2115-2138.

Kretz, R., 1983. Symbols for rock-forming minerals. American Mineralogist 68, 277-279.

Luvizotto, G.L., Zack, T., 2009. Nb and Zr behavior in rutile during high-grade metamorphism and retrogression: An example from the Ivrea-Verbano Zone. Chemical Geology 261, 303-317.

McDonough, W.F., Sun, S.s., 1995. The composition of the Earth. Chemical Geology 120, 223-253.

Mehnert, K.R., 1975. The Ivrea Zone: A model of the deep crust. Neues Jahrbuch Mineralogische Abhandlungen 125, 156-199.

Nehring, F., Jacob, D.E., Barth, M.G., Foley, S.F., 2008. Laser-ablation ICP-MS analysis of siliceous rock glasses fused on an iridium strip heater using $\mathrm{MgO}$ dilution. Microchimica Acta $160,153-163$.

Peressini, G., Quick, J.E., Sinigoi, S., Hofmann, A.W., Fanning, M., 2007. Duration of a Large Mafic Intrusion and Heat Transfer in the Lower Crust: a SHRIMP U-Pb Zircon Study in the Ivrea-Verbano Zone (Western Alps, Italy). Journal of Petrology 48, 11851218.

Pin, C., 1990. Evolution of the lower crust in the Ivrea Zone: a model based on isotopic and geochemical data, in: Vielzeuf, D., Vidal, P. (Eds.). Kluwer Academic Publisher, pp. 87110. 
Quick, J.E., Sinigoi, S., Negrini, L., Demarchi, G., Mayer, A., 1992. Synmagmatic deformation in the underplated igneous complex of the Ivrea-Verbano zone. Geology 20, 613-616.

Quick, J.E., Sinigoi, S., Mayer, A., 1994. Emplacement dynamics of a large mafic intrusion in the lower crust, Ivrea-Verbano Zone, northern Italy. Journal of Geophysical Research 99, 21559-21573.

Quick, J.E., Sinigoi, S., Mayer, A., 1995. Emplacement of mantle peridotite in the lower continental crust, Ivrea-Verbano zone, northwest Italy. Geology 23, 739-742.

Quick, J.E., Sinigoi, S., Snoke, A.W., Kalakay, T.J., Mayer, A., Peressini, G., 2003. Geologic map of the southern Ivrea-Verbano Zone northwestern Italy. U.S. Geological Survey, Geologic Investigations Series Map I-2776, scale 1:25,000.

Quick, J.E., Sinigoi, S., Peressini, G., Demarchi, G., Wooden, J.L., Sbisa, A., 2009. Magmatic plumbing of a large Permian caldera exposed to a depth of $25 \mathrm{~km}$. Geology 37, 603-606.

Redler, C., Johnson, T.E., White, R.W., Kunz, B.E., 2012. Phase equilibrium constraints on a deep crustal metamorphic field gradient: metapelitic rocks from the Ivrea Zone (NW Italy). Journal of Metamorphic Geology 30, 235-254.

Redler, C., White, R.W., Johnson, T.E., 2013. Migmatites in the Ivrea Zone (NW Italy): Constraints on partial melting and melt loss in metasedimentary rocks from Val Strona di Omegna. Lithos 175-176, 40-53.

Reinsch, D., 1973a. Die Metabasite des Valle Strona (Ivrea Zone). Neues Jahrbuch Mineralogische Abhandlungen 118, 190-210.

Reinsch, D., 1973b. Die Metabasite des Valle Strona (Ivrea Zone) (2.Teil). Neues Jahrbuch Mineralogische Abhandlungen 119, 266-284.

Rivalenti, G., Garuti, G., Rossi, A., 1975. The origin of the Ivrea-Verbano Basic Formation (western Italian Alps) - whole rock geochemistry. Bollettino della Società Geologica Italiana 94, 1149-1186. 
Rivalenti, G., Garuti, G., Rossi, A., Siena, F., Sinigoi, S., 1981. Existence of Different Peridotite Types and of a Layered Igneous Complex in the Ivrea Zone of the Western Alps. Journal of Petrology 22, 127-153.

Rudnick, R.L., Gao, S., 2003. Composition of the Continental Crust, in: Holland, H.D., Turekian, K.K. (Eds.), Treatise on Geochemistry. Elsevier, pp. 1-64.

Rushmer, T., 1991. Partial melting of two amphibolites: contrasting experimental results under fluid-absent conditions. Contributions to Mineralogy and Petrology 107, 41-59.

Rutter, E., Brodie, K., James, T., Burlini, L., 2007. Large-scale folding in the upper part of the Ivrea-Verbano zone, NW Italy. Journal of Structural Geology 29, 1-17.

Sawyer, E.W., 1991. Disequilibrium Melting and the Rate of Melt - Residuum Separation During Migmatization of Mafic Rocks from the Grenville Front, Quebec. Journal of Petrology 32, 701-738.

Sawyer, E.W., 2008. Atlas of Migmatites. The Canadian Mineralogist, Special Publication, 9. NRC Research Press, Ottawa, Ontario, Canada.

Sawyer, E.W., Cesare, B., Brown, M., 2011. When the continental crust melts. Elements 7, 229-234.

Schmid, R., 1967. Zur Petrographie und Struktur der Zone Ivrea-Verbano zwischen Valle d'Ossola und Val Grande (Prov. Novara, Italien). Schweizerische Mineralogische und Petrographische Mitteilungen 47, 935-1117.

Schmid, S.M., 1993. Pre-Mesozoic geology in the Alps, in: von Raumer, J.F., Neubauer, F. (Eds.). Springer, pp. 567-583.

Schmid, R., Wood, B.J., 1976. Phase relationships in granulitic metapelites from the IvreaVerbano zone (Northern Italy). Contributions to Mineralogy and Petrology 54, 255-279. Schmid, S.M., Zingg, A., Handy, M., 1987. The kinematics of movements along the Insubric Line and the emplacement of the Ivrea Zone. Tectonophysics 135, 47-66. 
Sills, J.D., Tarney, J., 1984. Petrogenesis and tectonic significance of amphibolites interlayered with metasedimentary gneisses in the Ivrea Zone, Southern Alps, northwest Italy. Tectonophysics 107, 187-206.

Sinigoi, S., Quick, J.E., Clemens-Knott, D., Mayer, A., Demarchi, G., Mazzucchelli, M., Nehrini, L., Rivalenti, G., 1994. Chemical evolution of a large mafic intrusion in the lower crust, Ivrea-Verbano Zone, northern Italy. Journal of Geophysical Research 99, 21,575$521,590$.

Sinigoi, S., Quick, J.E., Mayer, A., Budahn, J., 1996. Influence of stretching and density contrasts on the chemical evolution of continental magmas: an example from the IvreaVerbano Zone. Contributions to Mineralogy and Petrology 123, 238-250.

Sinigoi, S., Quick, J.E., Demarchi, G., Kloetzli, U., 2011. The role of crustal fertility in the generation of large silicic magmatic systems triggered by intrusion of mantle magma in the deep crust. Contributions to Mineralogy and Petrology 162, 691-707.

Sun, S.s., McDonough, W.F., 1989. Chemical and isotopic systematics of oceanic basalts: implications for mantle composition and processes. Geological Society, London, Special Publications 42, 313-345.

Vavra, G., Schmid, R., Gebauer, D., 1999. Internal morphology, habit and U-Th-Pb microanalysis of amphibolite-to-granulite facies zircons: geochronology of the Ivrea Zone (Southern Alps). Contributions to Mineralogy and Petrology 134, 380-404.

White, R.W., 2008. Insights gained from the petrological modelling of migmatites: particular reference to mineral assemblages and common replacement textures. Mineralogical Association of Canada, short course notes, 38, 77-96.

White, R.W., Powell, R. 2002. Melt loss and the preservation of granulite facies mineral assemblages. Journal of Metamorphic Geology 20, 621-632.

White, R.W., Powell, R., Halpin, J.A., 2004. Spatially-focussed melt formation in aluminous metapelites from Broken Hill, Australia. Journal of Metamorphic Geology, 22, 825-845. 
593 Wyllie, P.J., Wolf, M.B., 1993. Amphibolite dehydration-melting: sorting out the solidus.

594 Geological Society, London, Special Publications 76, 405-416.

595 Zingg, A., 1978. Regionale Metamorphose in der Ivrea Zone (Nord-Italien). PhD thesis, ETH 596 Zürich.

597 Zingg, A., 1980. Regional Metamorphism in the Ivrea Zone (Southern Alps, N-Italy): Field 598 and microscopic Investigations. Schweizerische Mineralogische und Petrographische $599 \quad$ Mitteilungen 60, 153-179.

600 


\section{Figure Captions}

Fig. 1. Simplified geological map of the central Ivrea Zone in the Southern Alps, Italy (compiled after Bigi et al., 1990; Rutter et al., 2007; Zingg, 1980). Mineral isograds after Schmid (1967) and Zingg (1980).

Fig. 2. Schematic map of Val Strona di Omegna showing sample localities. Mineral isograds are based on the first macroscopic appearance of the appropriate mineral in the field (see also e.g., Redler et al., 2012; Schmid, 1967; Zingg, 1980).

Fig. 3. Field relationships of metabasic rocks within the Kinzigite Formation in Val Strona di Omegna. (a) Typical fine-grained amphibolite with quartz vein from the mid amphibolite facies (sample IZ 014b; Loreglia). (b) Patch-migmatite close to the transition of the upper amphibolite to granulite facies. The leucosome forms irregular patches and large clinopyroxene porphyroblasts. (c) Stromatic migmatite foliation parallel leucosome (L1) and a discordant coarse-grained leucosome (L2) vein. The leucosomes mostly consist of plagioclase and quartz and contain peritectic clinopyroxene. (d) Metabasic granulite facies migmatite containing schlieren and schollen. The migmatite is dominated by melanosome (M) containing hornblende, clinopyroxene, orthopyroxene, garnet, biotite and minor plagioclase and quartz. The coarse-grained peritectic cpx-bearing leucosome occurs as network structures. (e) Metatexitic migmatite from the lowest granulite facies. The boudinaged melanosome (M) is surrounded by thin layers of fine-grained leucosome $\left(\mathrm{L}_{1}\right)$. Coarse grained leucosome enriched in clinopyroxene $\left(\mathrm{L}_{2}\right)$ forms pools within interboudin partitions. Above the boudin a coarse-grained leucocratic vein cross-cuts the rock $\left(\mathrm{L}_{3}\right)$. (f) Granulite facies metabasic rock with garnet porphyroblasts. The garnet shows reaction coronae of plagioclase, hornblende and ilmenite. (g) Metabasic migmatite in which the leucosome (L) formed a network structure around the melanosome (M). (h) The upper and lower part of the photograph is dominated by 
mesosomes consisting mostly of hornblende and clinopyroxene with minor plagioclase and quartz. $\mathrm{L}_{1}$ represents in situ leucosome formation in a pressure shadow of a fold. In source leucosome $\left(\mathrm{L}_{2}\right)$ has pooled above clinopyroxene. The leucosome $\left(\mathrm{L}_{3}\right)$ in the centre records migration of anatectic melt into veins. Below the leucosome vein residual material forms a mafic selvedge dominated by hornblende. (i) Metabasic rock with typical migmatite texture in Campello Monti. The leucosome contains large peritectic clinopyroxene porphyroblasts. (j) Close up of the leucosome shown in (i). The leucosome is coarser grained than the melanosome and consists mostly of plagioclase with minor quartz \& K-feldspar. Large clinopyroxene porphyroblasts in the leucosome are partially replaced by hornblende.

Fig. 4. Petrography of the metabasic rocks in Val Strona di Omegna (scale bar $1 \mathrm{~mm}$ ). (a) Mid amphibolite facies sample containing lepidoblastic hornblende and biotite crystals. In some place the hornblende and biotite are intergrown while in other the hornblende is replaced by biotite. The biotite crystals define a foliation. (b) (crossed polars) Metabasic rock from the upper amphibolite facies (IZ 035) containing clinopyroxene in the matrix as well as porphyroblasts. The matrix minerals (clinopyroxene, plagioclase and hornblende) are general relative equigranular however in some areas (white rectangular) the crystals become coarser grained and often show $120^{\circ}$ angle between mineral grains. (c) Granulite facies sample with the mineral assemblage clinopyroxene, orthopyroxene, garnet, brown hornblende, plagioclase, ilmenite and secondary biotite. Most mineral grains show triple junctions with an angle of $120^{\circ}$. (d) Highest grade sample (IZ 100, Campello Monti, see Fig. 2) from the granulite facies containing the peak mineral assemblage clinopyroxene, orthopyroxene, garnet, plagioclase and ilmenite. Brown hornblende and biotite in this sample are only present as secondary replacements. (e) Granulite facies migmatite with leucosome and melanosome domains. The area from the left to the middle is dominated by quartz and plagioclase with minor clinopyroxene (leucosome). The upper right corner is enriched in clinopyroxene, hornblende, 
653

654

655

656

657

658

659

660

661

662

663

664

665

666

667

668

669

670

671

672

673

674

675

676

677

orthopyroxene, biotite and ilmenite with only minor plagioclase and quartz (melanosome).

The grain size in the leucosome domain is in general larger than in the melanosome domain.

(f) (crossed polars) Leucosome vein with large plagioclase and quartz grains compared to 'normal' granulite facies grain sizes (right side). The leucosome is bordered by a mafic selvedges enriched in brown, hornblende. (g) Garnet reaction corona (Fig. 3f). The garnet is rimed by plagioclase, ilmenite and brown hornblende. (h) Retrograde replacement of highgrade mineral assemblages occurs in several steps. Clinopyroxene gets replaced by brown hornblende, which then is replaced by biotite (white arrows) and/or actinolite.

Fig. 5. Harker variation diagrams showing the concentrations of major elements (wt\%) in metabasic rocks from Val Strona di Omegna. Average values of the middle and lower continental crust are taken from Rudnick and Gao (2003).

Fig. 6. (a-c) Trace element composition of metabasic rocks from Val Strona di Omegna normalised to primitive mantle (McDonough and Sun, 1995). The values for N-MORB (Hofmann, 1988; Sun and McDonough, 1989) and E-MORB (Sun and McDonough, 1989) and the middle and lower continental crust (Rudnick and Gao, 2003) are shown. (d) Comparison of trace elements content of mafic rocks (amphibole gabbros \& norites) from the Mafic Complex, Val Sessera (Sinigoi et al., 2011) with metabasic rocks (this study) from the Kinzigite Formation in Val Strona di Omegna (Campello Monti).

Fig. 7. (a-c) REE composition of metabasic rocks from Val Strona di Omegna normalised to CI Chondrite (McDonough and Sun 1995). The values for N-MORB and E-MORB are from Hofmann (1988) and Sun and McDonough (1989), for the middle and lower continental crust, Rudnick and Gao (2003). (d) Comparison of REE content of mafic rocks (amphibole gabbros 
678 \& norites) from the Mafic Complex, Val Sessera (Sinigoi et al., 2011) with metabasic rocks

679 (this study) from the Kinzigite Formation in Val Strona di Omegna (Campello Monti).

680

681 Fig. 8. Diagrams showing average major (a), trace (b) and rare earth (c) element composition

682 of the upper amphibolite and granulite facies normalised to the average mid amphibolite

683 facies composition. (a) The average major elements composition of the upper amphibolite and

684 granulite facies show a depletion in $\mathrm{SiO}_{2}, \mathrm{Al}_{2} \mathrm{O}_{3}, \mathrm{Na}_{2} \mathrm{O}$ and $\mathrm{K}_{2} \mathrm{O}$ compared to average mid

685 amphibolite samples, whereas $\mathrm{TiO}_{2}, \mathrm{FeO}, \mathrm{MnO}, \mathrm{MgO}$ and $\mathrm{CaO}$ are enriched. (b) The trace

686 elements of the upper amphibolite and granulite facies are depleted in LILE. The HFSE show

687 values similar to average mid amphibolite facies samples. (c) The LREE are depleted in the

688 upper amphibolite facies while the granulites show values close to average mid amphibolite

689 facies concentration. The average upper amphibolite and granulite facies compositions show a

690 slightly HREE enrichment compared to mid amphibolite facies samples.

691 


\section{Table Captions}

693

694 Table 1. Major mineral assemblages of representative metabasic rocks from Val Strona di 695 Omegna.

696

697 Table 2. Whole rock major and trace element composition of representative metabasic rocks

698 from Val Strona di Omegna. Iron contents are expressed as all ferric. Trace elements marked 699 with an asterisk were measured by XRF, all other by LA-ICP-MS. 


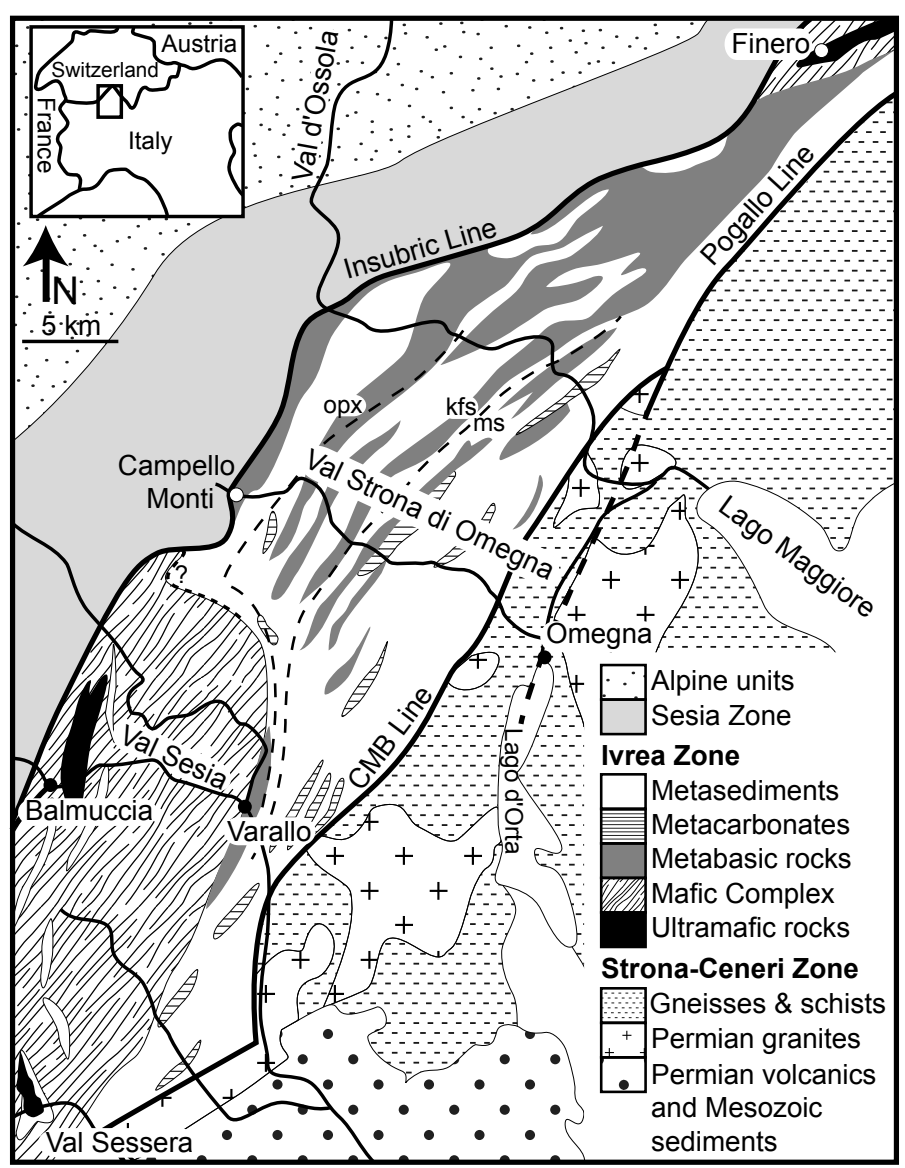




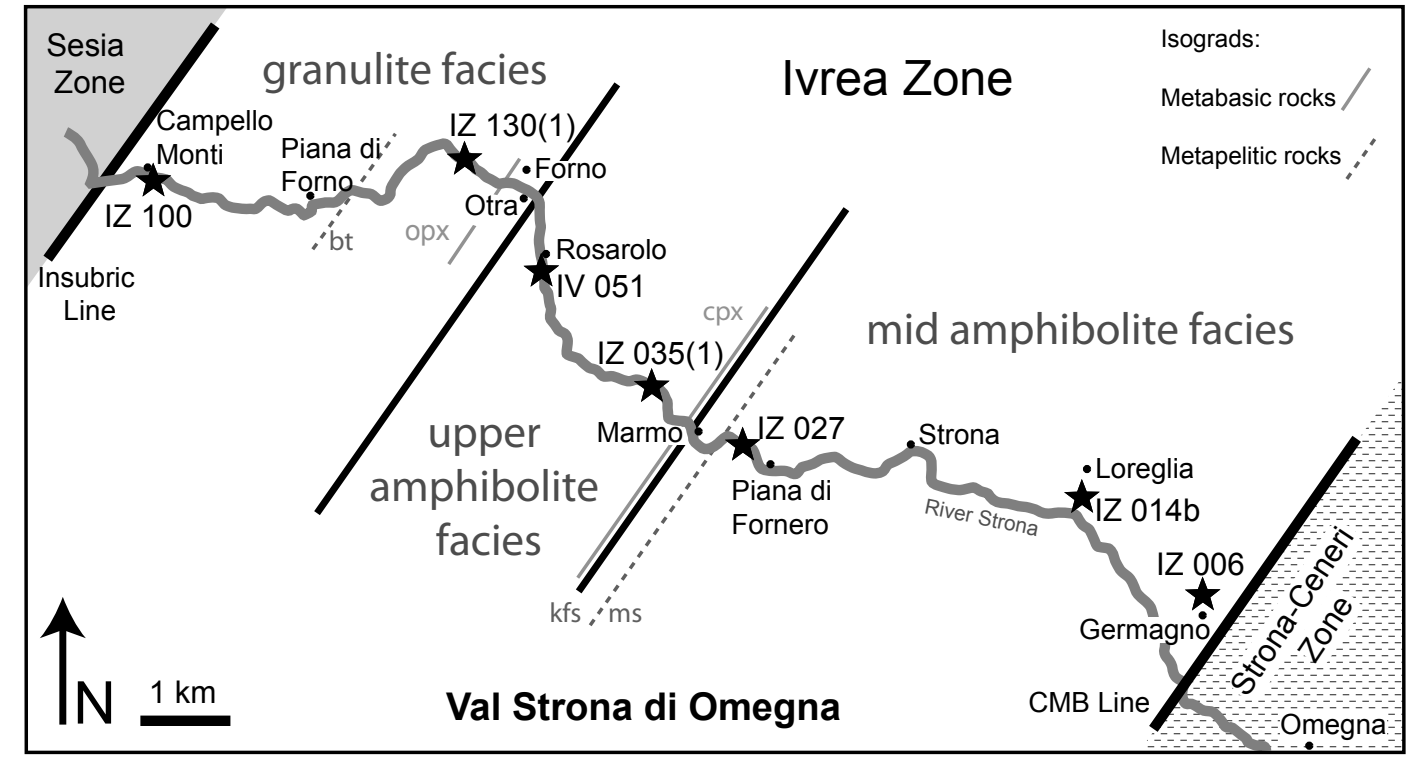


Click here to download high resolution image
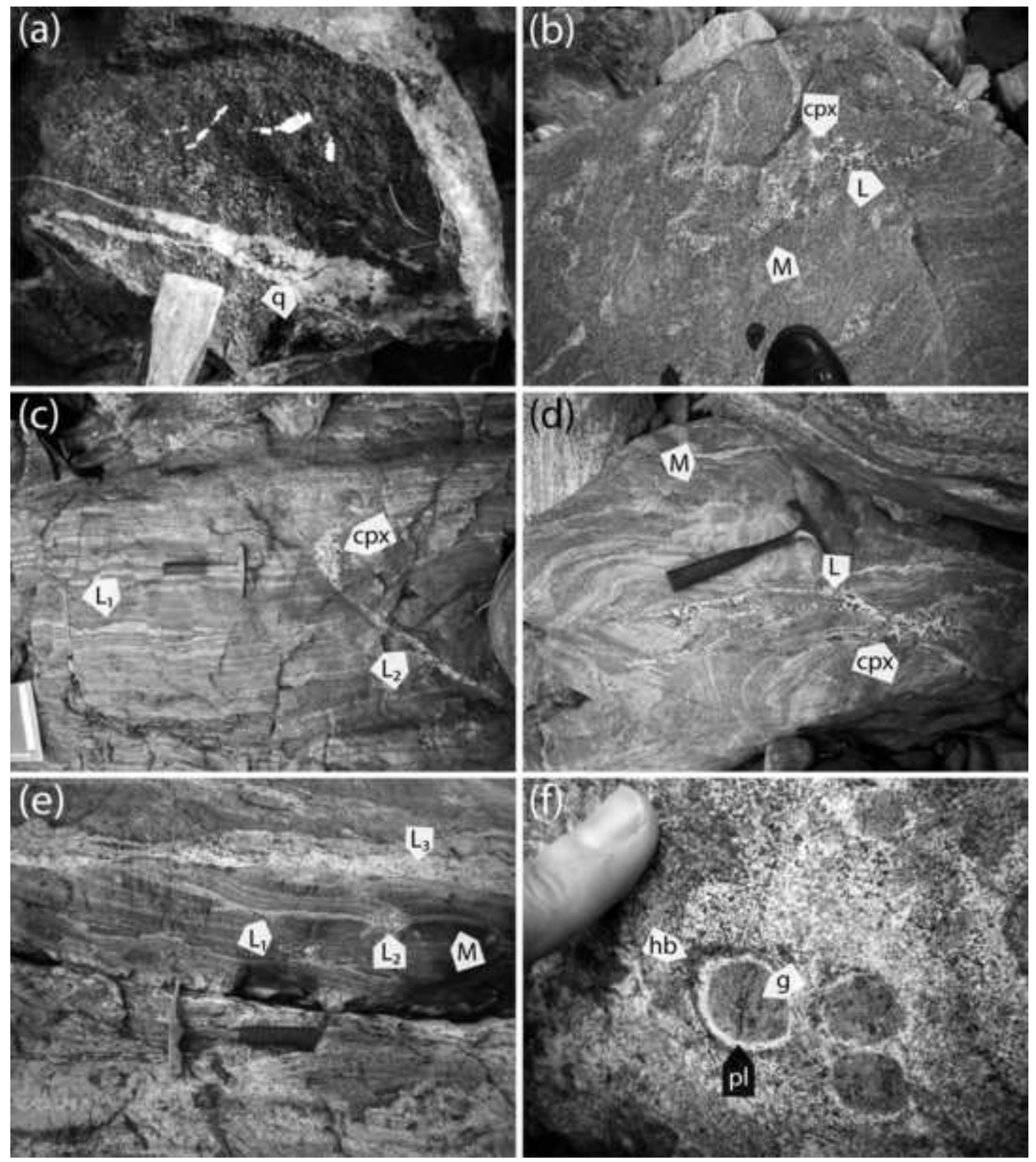
Click here to download high resolution image
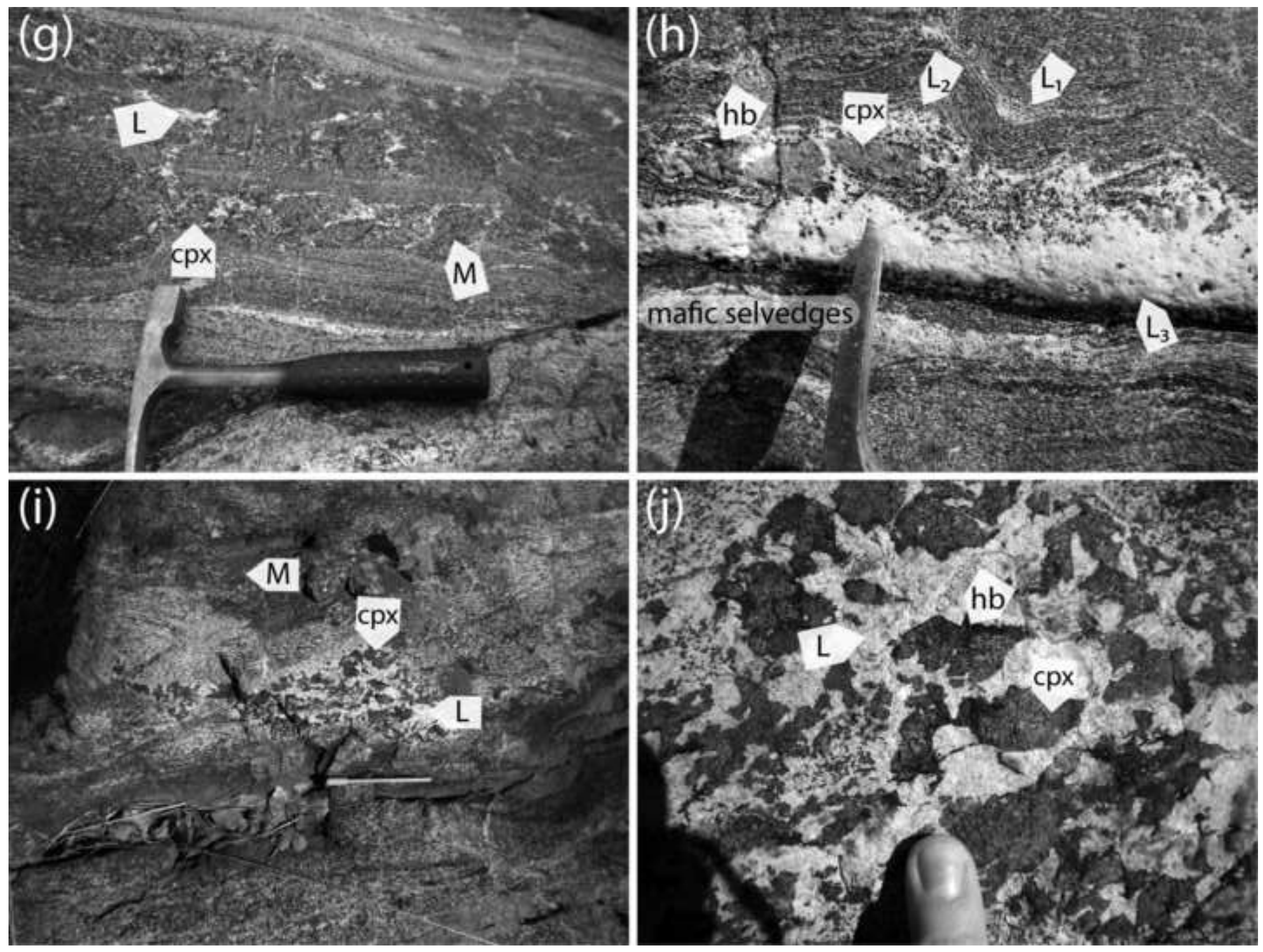

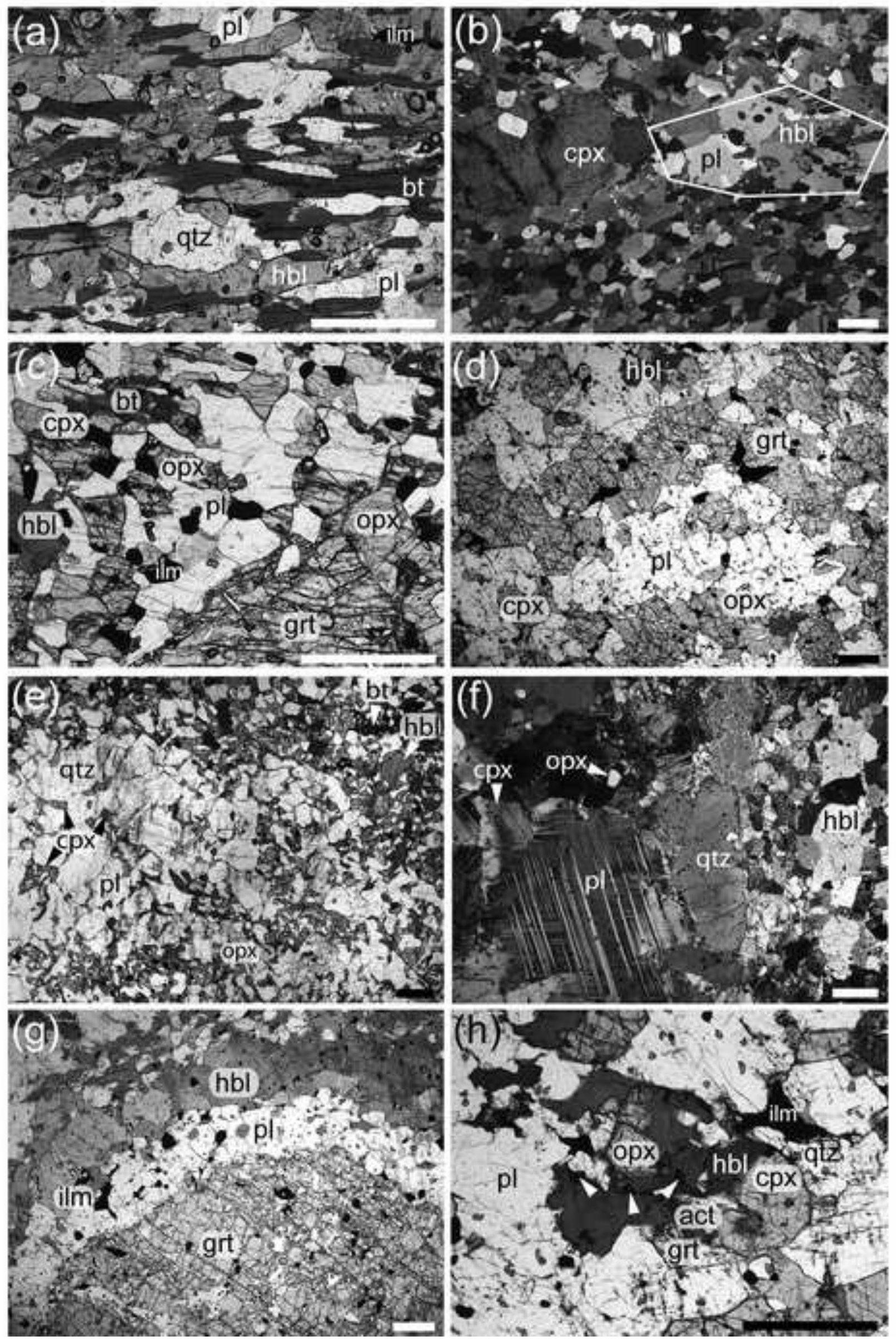

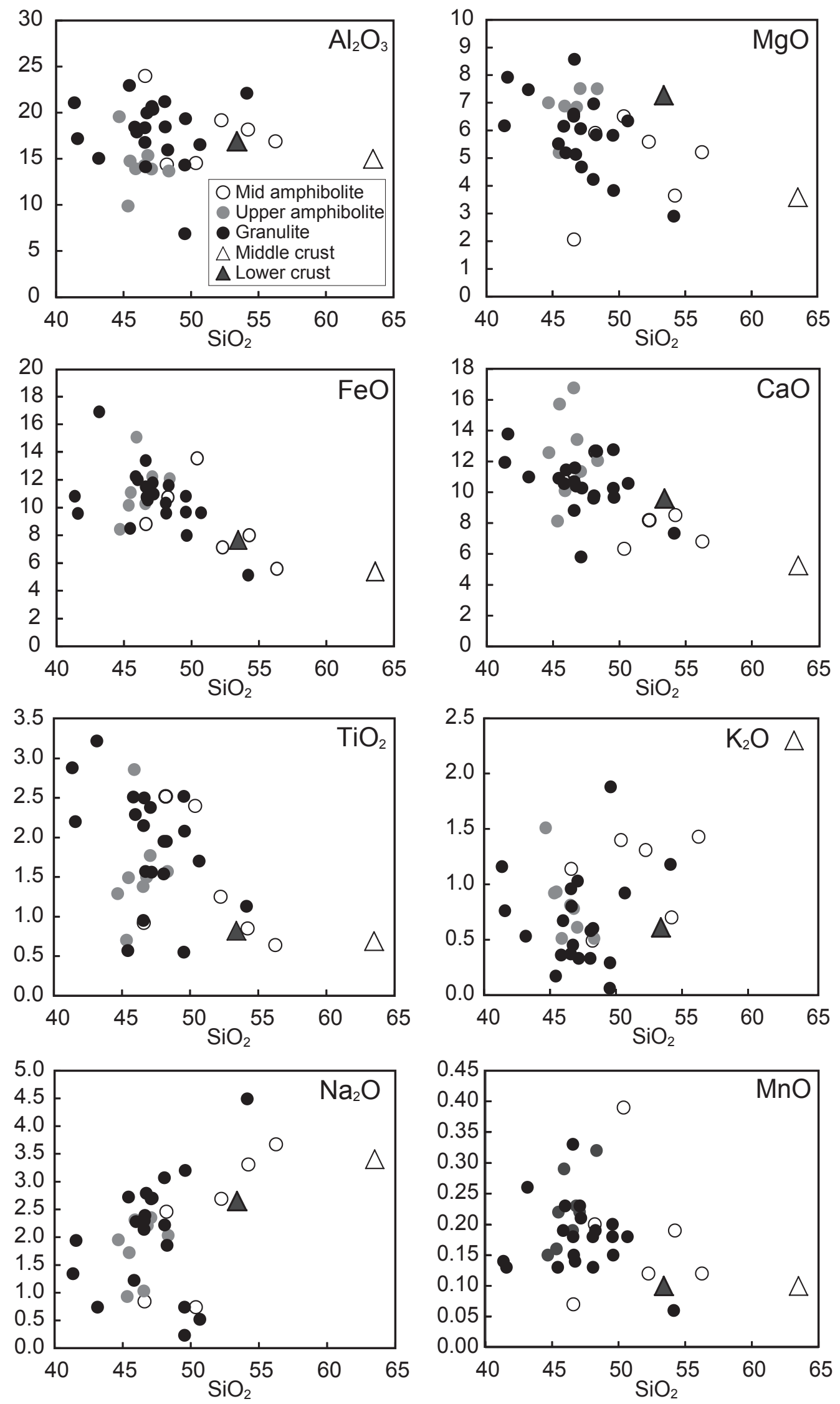


\section{Figure6}
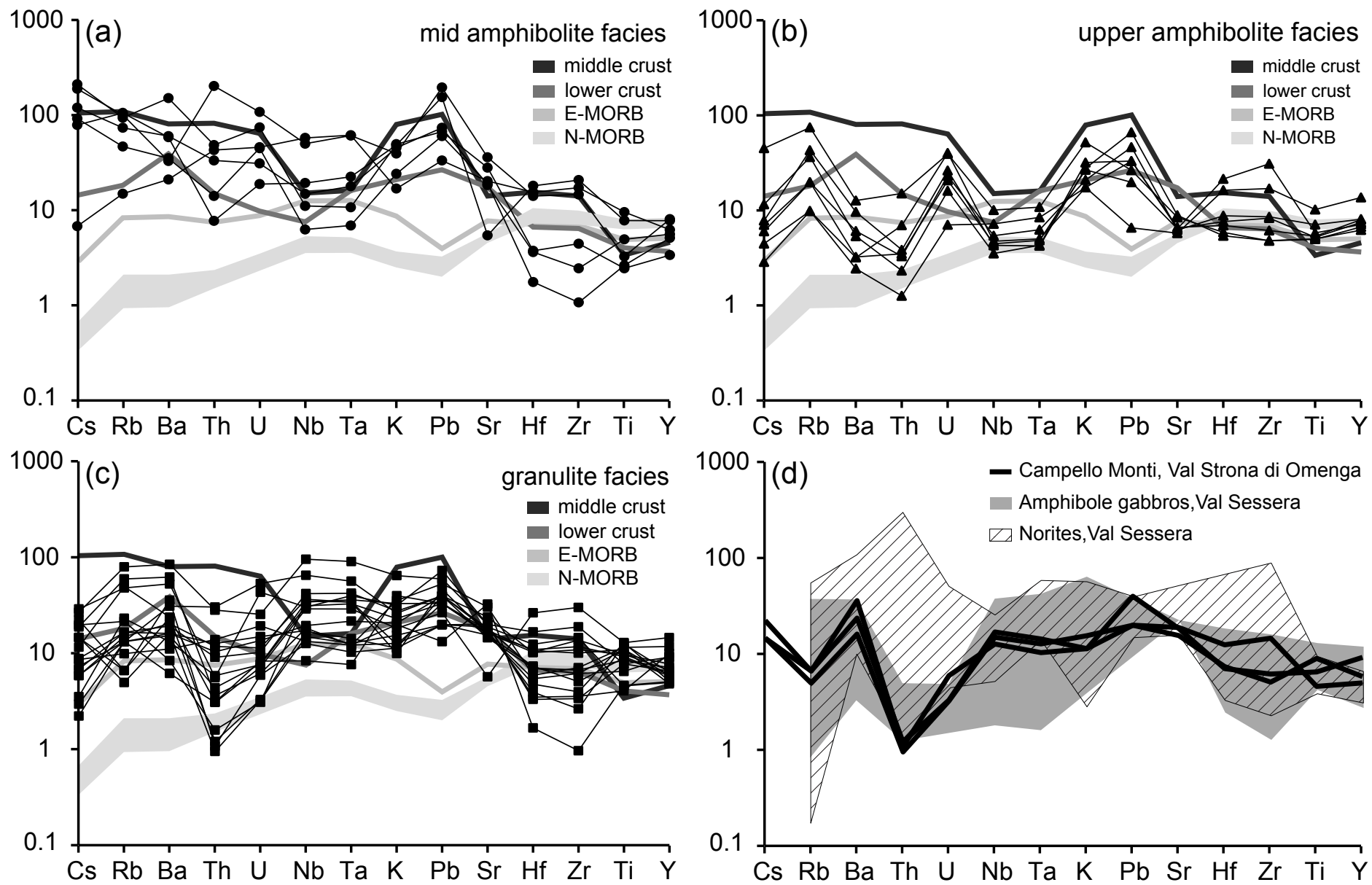

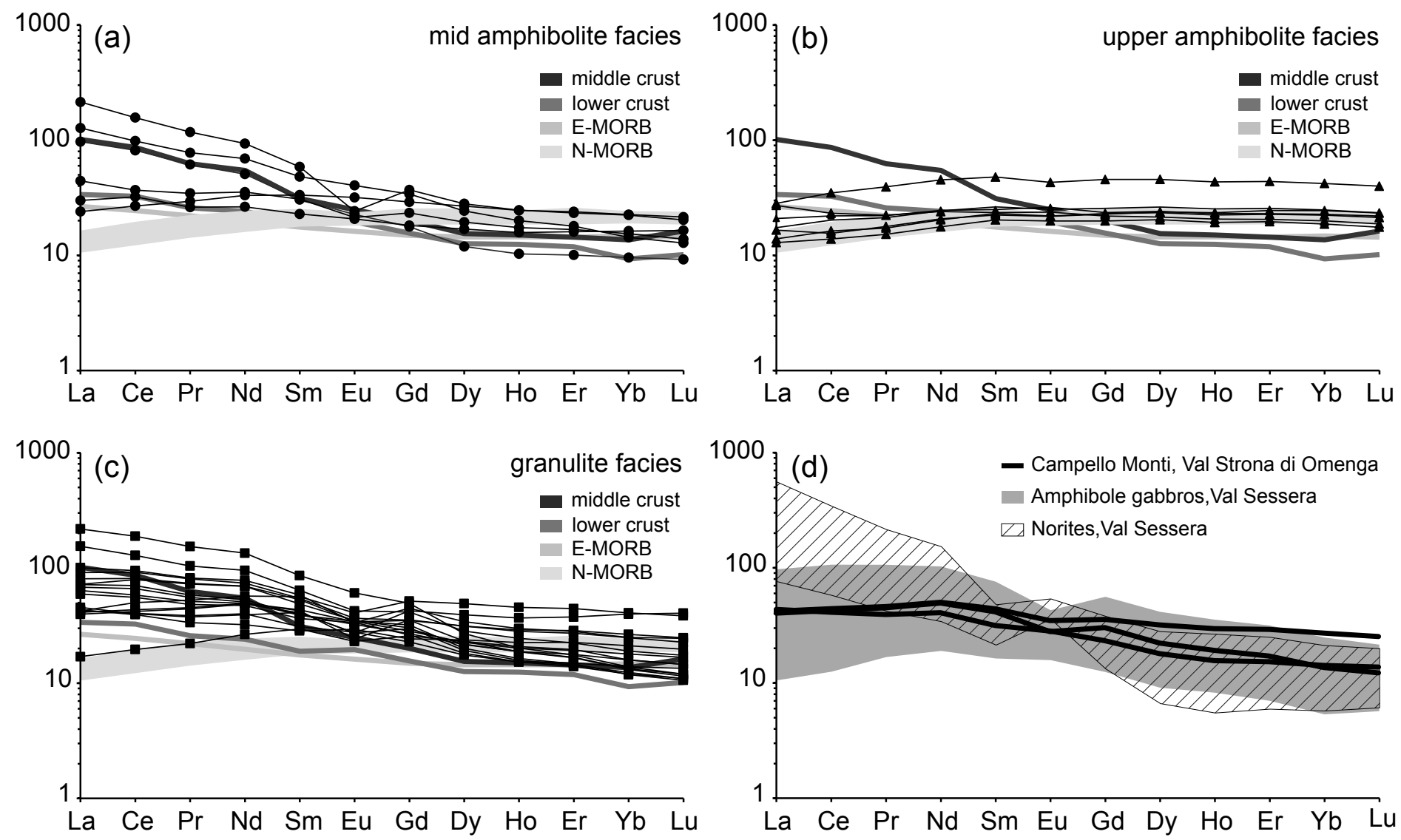
Figure8
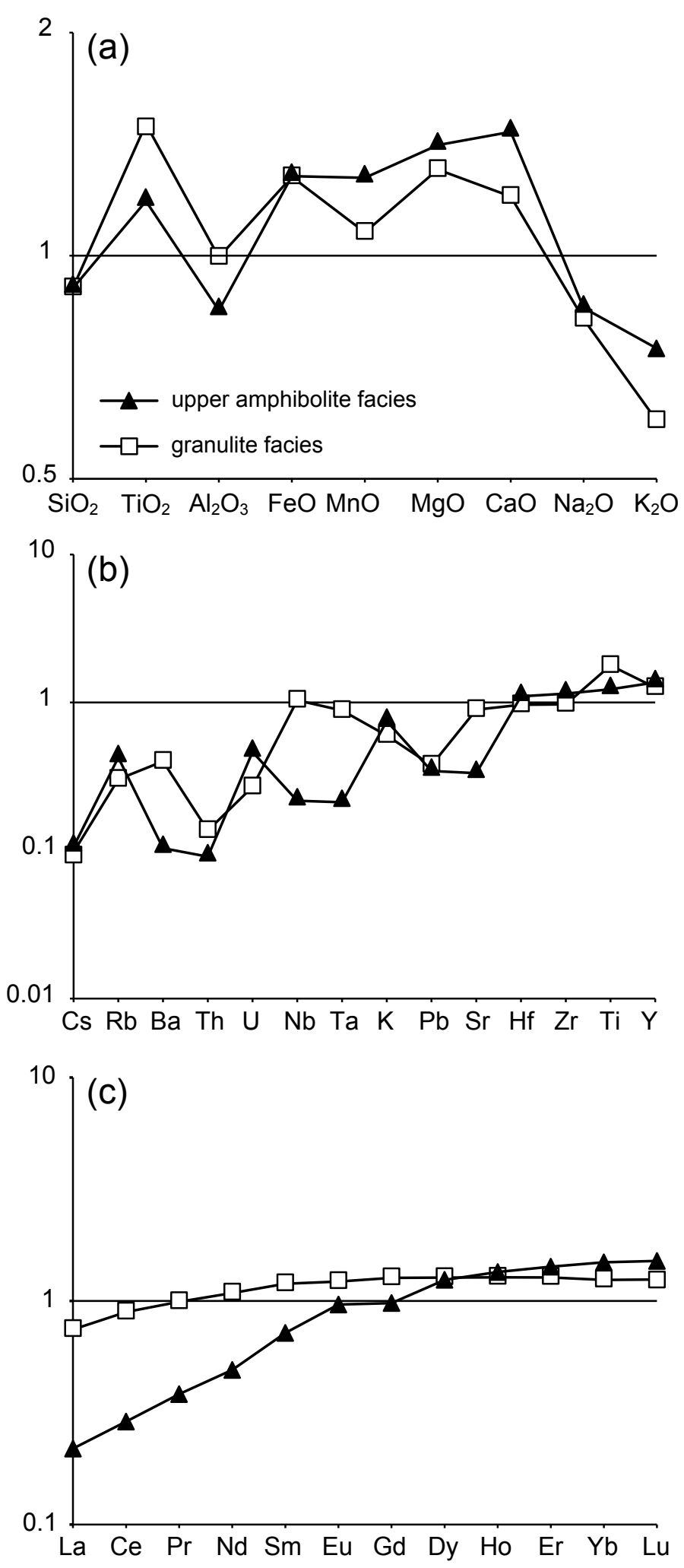


\begin{tabular}{|c|c|c|c|c|c|c|c|c|c|c|c|c|}
\hline \multirow[t]{2}{*}{ Sample } & \multirow[t]{2}{*}{ Lithology } & \multirow[t]{2}{*}{ Locality } & \multicolumn{2}{|c|}{ Coordinates } & \multicolumn{8}{|c|}{ Mineral assemblage } \\
\hline & & & $\mathrm{E}$ & $\mathrm{N}$ & grt & opx & cpx & hbl & $\mathrm{pl}$ & qtz & ilm & bt \\
\hline \multicolumn{13}{|c|}{ Mid amphibolite facies } \\
\hline IZ 006 & Amphibolite & Germagno & 452603 & 5082335 & & & & $\mathrm{x}$ & $\mathrm{x}$ & $\mathrm{x}$ & $\mathrm{x}$ & $\mathrm{x}$ \\
\hline IZ 014b & Amphibolite & Loreglia & 451414 & 5083567 & & & & $\mathrm{x}$ & $\mathrm{x}$ & $\mathrm{x}$ & $\mathrm{x}$ & $\mathrm{x}$ \\
\hline IZ 027 & Grt-Amphibolite & Piana di Fornero & 447499 & 5084130 & $\mathrm{x}$ & & & $\mathrm{x}$ & $\mathrm{x}$ & $\mathrm{x}$ & $\mathrm{x}$ & $\mathrm{x}$ \\
\hline \multicolumn{13}{|c|}{ Upper amphibolite facies } \\
\hline IZ $035(1)$ & Cpx-Amphibolite & Marmo & 446520 & 5084830 & & & $\mathrm{x}$ & $\mathrm{x}$ & $\mathrm{x}$ & $\mathrm{x}$ & $\mathrm{x}$ & \\
\hline IV 051 & Metabasic Migmatite & Rosarolo & 445186 & 5086123 & & & $\mathrm{x}$ & $\mathrm{x}$ & $\mathrm{x}$ & $\mathrm{x}$ & $\mathrm{x}$ & \\
\hline \multicolumn{13}{|c|}{ Granulite facies } \\
\hline IZ 130(1) & Metabasic Migmatite & Forno & 444403 & 5087354 & $\mathrm{x}$ & $\mathrm{x}$ & $\mathrm{x}$ & $\mathrm{x}$ & $\mathrm{x}$ & $\mathrm{x}$ & $\mathrm{x}$ & $\mathrm{x}$ \\
\hline IZ 161(1) & Metabasic Migmatite & Piana di Forno & 443516 & 5086975 & $\mathrm{x}$ & $\mathrm{x}$ & $\mathrm{x}$ & $\mathrm{x}$ & $\mathrm{x}$ & $\mathrm{x}$ & $\mathrm{x}$ & $\mathrm{x}$ \\
\hline IZ 100 & Metabasic Migmatite & Campello Monti & 440934 & 5087103 & $\mathrm{x}$ & $\mathrm{x}$ & $\mathrm{X}$ & $\mathrm{X}$ & $\mathrm{x}$ & $\mathrm{X}$ & $\mathrm{x}$ & $\mathrm{X}$ \\
\hline
\end{tabular}




\begin{tabular}{|c|c|c|c|c|c|c|c|c|}
\hline Sample & IZ 006 & IZ 014b & IZ 027 & IZ $035(1)$ & IV 051 & IZ 130(1) & IZ 161(1) & IZ 100 \\
\hline \multicolumn{9}{|c|}{ Major elements (wt\%) } \\
\hline $\mathrm{SiO}_{2}$ & 54.22 & 52.25 & 50.37 & 48.35 & 45.90 & 48.27 & 45.99 & 47.17 \\
\hline $\mathrm{TiO}_{2}$ & 0.85 & 1.25 & 2.40 & 1.57 & 2.86 & 1.95 & 2.29 & 1.56 \\
\hline $\mathbf{A l}_{2} \mathbf{O}_{3}$ & 18.16 & 19.18 & 14.53 & 13.68 & 13.91 & 15.96 & 17.90 & 20.35 \\
\hline $\mathbf{F e}($ total) & 8.94 & 7.95 & 15.13 & 13.49 & 16.84 & 12.95 & 13.41 & 12.26 \\
\hline MnO & 0.19 & 0.12 & 0.39 & 0.32 & 0.29 & 0.19 & 0.23 & 0.21 \\
\hline MgO & 3.64 & 5.59 & 6.51 & 7.50 & 6.88 & 5.84 & 5.19 & 4.68 \\
\hline $\mathrm{CaO}$ & 8.51 & 8.18 & 6.33 & 12.05 & 10.09 & 12.66 & 11.44 & 10.27 \\
\hline $\mathrm{Na}_{2} \mathrm{O}$ & 3.31 & 2.69 & 0.74 & 2.03 & 2.31 & 1.85 & 2.28 & 2.70 \\
\hline $\mathbf{K}_{2} \mathbf{O}$ & 0.70 & 1.31 & 1.40 & 0.51 & 0.51 & 0.60 & 0.67 & 0.33 \\
\hline $\mathbf{P}_{2} \mathbf{O}_{5}$ & 0.19 & 0.10 & 0.23 & 0.12 & 0.26 & 0.17 & 0.29 & 0.30 \\
\hline $\mathrm{SO}_{3}$ & 0.02 & -0.01 & 0.36 & 0.02 & 0.00 & 0.03 & 1.37 & 0.05 \\
\hline Sum & 99.60 & 99.99 & 101.00 & 100.09 & 100.21 & 100.54 & 101.61 & 99.96 \\
\hline LOI & 0.86 & 1.36 & 2.57 & 0.41 & 0.35 & 0.02 & 0.51 & 0.07 \\
\hline \multicolumn{9}{|c|}{ Trace elements (ppm) } \\
\hline $\mathbf{L i}$ & 40.34 & 21.61 & 39.49 & 11.85 & 9.31 & 6.59 & 6.85 & 3.35 \\
\hline $\mathrm{Sc}^{*}$ & 31.00 & 32.00 & 44.00 & 50.00 & 54.00 & 43.00 & 45.00 & 40.00 \\
\hline $\mathbf{T i}$ & 3212.31 & 6018.29 & 9477.04 & 6391.21 & 12466.21 & 10283.52 & 11856.28 & 7866.95 \\
\hline $\mathbf{V}$ & 239.90 & 307.45 & 379.38 & 305.69 & 457.12 & 256.56 & 290.30 & 226.45 \\
\hline $\mathrm{Cr}^{*}$ & 25.00 & 16.00 & 98.00 & 179.00 & 63.00 & 177.00 & 112.00 & 18.00 \\
\hline Mn & 1419.20 & 915.03 & 2692.72 & 2085.01 & 1967.21 & 1243.41 & 1616.68 & 1478.14 \\
\hline $\mathrm{Ni}^{*}$ & 14.00 & 8.00 & 58.00 & 68.00 & 57.00 & 66.00 & 61.00 & 18.00 \\
\hline $\mathbf{R b}^{*}$ & 28.00 & 44.00 & 63.00 & 6.00 & 6.00 & 10.00 & 14.00 & 4.00 \\
\hline $\mathbf{S r}$ & 381.20 & 366.64 & 109.35 & 130.47 & 116.42 & 290.86 & 327.13 & 367.15 \\
\hline $\mathbf{Y}$ & 22.22 & 24.25 & 33.68 & 32.64 & 59.53 & 30.76 & 28.78 & 39.76 \\
\hline $\mathbf{Z r}$ & 11.47 & 26.10 & 218.57 & 88.46 & 180.32 & 70.90 & 144.92 & 65.18 \\
\hline Nb & 4.17 & 9.81 & 12.77 & 3.17 & 4.82 & 12.88 & 20.69 & 11.19 \\
\hline Cs & 1.92 & 2.50 & 1.65 & 0.10 & 0.06 & 0.19 & 0.07 & 0.31 \\
\hline $\mathbf{B a}$ & 232.24 & 395.74 & 385.66 & 21.47 & 16.40 & 107.23 & 87.42 & 156.67 \\
\hline La & 7.10 & 10.50 & 5.68 & 4.95 & 6.67 & 10.33 & 16.26 & 9.83 \\
\hline $\mathrm{Ce}$ & 19.76 & 22.59 & 16.45 & 13.47 & 21.32 & 24.30 & 40.77 & 26.75 \\
\hline $\operatorname{Pr}$ & 2.43 & 3.21 & 2.73 & 2.05 & 3.64 & 3.13 & 5.19 & 4.22 \\
\hline Nd & 12.06 & 16.18 & 15.17 & 11.21 & 20.63 & 14.83 & 23.31 & 22.69 \\
\hline Sm & 3.38 & 4.56 & 4.94 & 3.69 & 7.07 & 4.24 & 5.79 & 6.44 \\
\hline Eu & 1.17 & 1.20 & 1.79 & 1.47 & 2.42 & 1.66 & 1.95 & 1.93 \\
\hline Gd & 3.62 & 4.65 & 5.79 & 4.67 & 9.06 & 4.86 & 5.67 & 7.01 \\
\hline Dy & 4.16 & 4.78 & 6.59 & 5.91 & 11.20 & 5.88 & 5.60 & 7.75 \\
\hline Ho & 0.86 & 0.95 & 1.34 & 1.26 & 2.37 & 1.24 & 1.10 & 1.60 \\
\hline $\mathbf{E r}$ & 2.57 & 2.68 & 3.82 & 3.67 & 7.00 & 3.64 & 3.10 & 4.60 \\
\hline $\mathbf{Y b}$ & 2.62 & 2.48 & 3.64 & 3.65 & 6.76 & 3.43 & 2.91 & 4.30 \\
\hline Lu & 0.40 & 0.34 & 0.53 & 0.54 & 0.98 & 0.49 & 0.41 & 0.61 \\
\hline Hf & 0.51 & 1.04 & 5.13 & 2.19 & 4.67 & 1.99 & 2.92 & 2.00 \\
\hline Ta & 0.26 & 0.66 & 0.83 & 0.19 & 0.32 & 0.81 & 1.22 & 0.53 \\
\hline $\mathbf{P b}^{*}$ & 9.00 & 11.00 & 23.00 & 5.00 & 1.00 & 6.00 & 5.00 & 6.00 \\
\hline Th & 1.13 & 2.66 & 0.62 & 0.56 & 0.10 & 0.83 & 0.47 & 0.10 \\
\hline $\mathbf{U}$ & 0.91 & 0.63 & 0.38 & 0.82 & 0.15 & 0.28 & 0.16 & 0.07 \\
\hline
\end{tabular}

